\title{
脊柱側彎症と平衡機能
}

\author{
山去望簤吾
}

\section{I. 研 究の発端}

檜教授が徳島大学医学部に御着任になられてからもう10年にもなる。私は京大の同空というとと でも随分㧍親しくさせて戴いたし，殊に学問の面では色々と御指導，御支援を戴き感謝に堪えない.

あっとあ，耳鼻咽喉科と整形外科とは専攻する学問分野の面で相等な隔絶があるように見えるの が一般だが，奇しくも両者の主体研究が姿勢平衡であったということから仕事の面であ密接な関連 を生じ，友情に一層の深さを加えることになったととは幸せであった。

周知の通り，整形外科は，Haglund ${ }^{1)}$ が定義しているように，姿勢と運動に関する病理と治療を 講ずる学問である。私は整形外科領域の中であ特に脊椎外科を中心に約 40 年間研究を深めて来たし， 最近15年間は側彎症を主体研究として精根を傾けて来た.

ところで，側彎症は病気の特質 (Krankheits-bezeichnung) を表わす語ではなく，脊柱変形の病的 状態 (Krankheitsbefund) 2) を示す言葉である. これは成長期の少年，少女の約 $1 \%$ (本邦内の地域 差はほとんどない）にも見られるという高い発生頻度を示す疾患であり，その原因の如何を問わず 成長期を通じ増悪傾向を示し，放置すれば駱幹の著しい醜形と胸腹部内臟や下肢に重大な機能障害 をあたらす点で社会的意義の大きな疾病である。しかも，その大部分は特発性側彎症に属し，原因 が不明であるということからあ学問的興味のひかれる特異な疾患である.

ところで，特発性側彎症が特発性たる所以は，その病因の解明が困難なるが故にその診断が低迷 状態にあると言うことであって，特別な独立疾患であるという訳のあのではない.

少なくと屯現在までに採られた解明方法ではその原因を確実に把むととができなかった．

従って，乙の点を解決するととができれば側彎症の領域に大きな進歩を加えることになろう.

言うまでもなく，本症では脊柱は大なり小なり側方に曲がり，多少の捻転を伴っている.

特に特発性側彎症では彎曲の進行性増悪を特徵としているが，椎骨や椎間板には病理学的にも生 化学的にも一次的病因を発見し得なかったし，軁幹筋や支配神経にも一次的原因が見出された訳で あない。ただひたすらに曲がるけれどあ，特発性側彎症には局所的原因が発見されないというのが 從来の共通理解である.

このように，特発性側彎症が局所的要因によって発生するあのでないとすれば，全身的要因を探 し求める必要屯当然生じてくる.

全身的要団として，内分泌系の異常にその原因を求めようとした研究者 ${ }^{314)}$ 屯かなりいるが，い ずれあ明確な所見を立証することができなかった。一方，姿勢制御機構という観点から中枢神経系 に探索が進められた研究もあるが，多くは単発的に異常例の報告にとどまり，精密な総括的検討は

Equilibrium Function in scoliosis

Kengo Yamada

徳島大学学長 
ほとんど行われなかった．私はこの点が特に重要と考えるあのであり，本症解明の鍵がここにある のではないかと考えた次第である.

いずれにしても，以上の事柄は思考方向の基本的問題に関連することであり，端的に言うなら ば，部分から全体へ，分析から総合への思考的転換を意味するあのであある.

上述のように, 特発性側彎症には脊柱の基本的構成体, すなわち, 椎骨や椎間板そのものには本 質的な異常が証明されないとされているので，脊柱をその構成の基本的要素，すなわち，部分に分 解して解明しようとするような分析的方法では，従来と同じようなデッドロックに導くことにあな りかねない，従って，そのアプローチの方向を従来とは逆方向，全体的，総合的視野に立った路線 に変更するならば，あるいは本問題解決の緒を把むととができるかも知れない.

それで，特発性側彎症については，その脊柱の彎曲による姿勢の崩れが，構成体たる個々の椎 骨, 椎間板の異常集積によってもたらされたとするよりも, 姿勢の崩れが脊柱の彎曲を招来したと いう風に発想の転換ができないものだろうか.

整形外科の日常診療では，しばしば 1 枚の脊柱レ線写真を示して，彎曲が $\mathrm{S}$ 型だからバランスの 良い側彎だとか，C型だからバランスが悪いとか言うことがある．しかし，人体のバランスは極め て複雑な機構によって保持されるあのであり, 単なる1枚のレントゲン写真の絵がそのすべてを表 現しているとは思えないし，ましてや，主観的な美的感情が背骨のバランスの良否を判定し得るよ うなあのではない。言うまであなく，身体の平衡は中枢神経支配の高次の統合調整が姿勢や運動と して外面的に表出されたものであって，実践的な臨床の場を通じ客観的事実として明確に把握され なければならないむのと考える.しかし，当初の段階では，側彎症に平衡異常が現実に合併し得る か否か, どのような検査法で発見し得るかというような幾つかの疑問が未解決のまま私の脳裡を占 めていた. 勿論, 文献屯渉猟してみたし，ての分野の権威の意見も徴したが，乙の方面に知識の乏 しい私には確実な理解を得るまでには至らなかった。

たまたま，昭和 41 年 9 月檜教授が着任され挨拶のため私の部屋を訪ねられた．抒互の挨拶屯そこ そこに私は日頃の疑問を打ちあけ檜教授の意見と助力を求めた. 檜教授はこの問題に非常な興味を 示され，専門的立場から側彎症患者の平衡機能を検査してみようと言うととになった．檜教授の検 査結果では側彎症患者には単なる立ち直り反射の異常だけでなく，脊柱とは直接関係のない上肢や 眼にあ明らかな偏倚現象を証明し得ると指摘された。乙れは正に驚くべきことであった。そこで， 側彎症患者を耳鼻科教室に紹介し検査して戴くと共に, 整形外科の教室員を耳鼻科教室に派遣し検 査法を習得させることにした.

問題の重要性に鑑み，検査者の主観を排除してデータの客観的正確さを確保するために，個々の 患者について両教室がそれぞれ独立検査を行い, blind testの結果を両教室合同の討論会席上で照 合するととになった，そして，両教室の検査成績は完全に合致するととが確認された．との喜びは 誠に大きく，討論会終了後両教室合同で祝盃をあげることになった．ところが，アルコホールの回 り具合がすばらしく早く，飲むほどに酔うほどに忽ちダウンする者が続出（空腹を忘れてカンファ レンスをやっていたためらしい），私も相当グロッキーになって檜教授に家まで送って戴く羽目に なった。そして，自宅の玄関の柱に最敬礼をし，したたか額を打ちつけたという醜態を演じてしま ったが，学問と友情の二重の喜びはありし良き日の忘机難い感激でああった。その後研究が急速な 発展を見たことは言うまでもない.

以上私共の研究成果の大要を記載する. 


\section{II．脊柱側彎症における平衡機能}

1）臨床調査および野外調査5)

側彎症 150 例について平衡機能を検査した。 検査法は福田の方法により立ち直り反射検査, 偏倚検査，実験眼振検査を行なった。 異常出現 率に関しては，立ち直り検査に属するロンベル グ検査では陽性は 145 例中 23 例，16.6\%，同じ く単脚直立検査では陽性142例中78例，54.9\%， マン氏検査では陽性は 142 例中 65例，45.8\%， ゴニオメーター検査では陽性141例中44例, 31.2 \%であった，次に偏倚検査に属する遮眼書字検 査では陽性は 140 例中 79例，56.4\%，眼の偏倚 検査（裸眼注視時の眼振様異常眼運動，フレン ツェル眼鏡装用下の自発眼振）は150 例中陽性 は83例，55.3\%ああった。但し「めまい」感を 訴えるあのは 1 例むなかった，最後に，実験眼 振検査として視運動性眼振検査陽性は64例中46 例，71.8\%あった。

とあかく，いずれかの検査で陽性を示したも のは側彎症150例中119例，79.3\%であった。

これと比較のため，春柱正常20例，後彎を示 す12例の成長期少年少女について同様の検查を 行なった。平衡異常の合併率は佘柱正常例では $5 \%$ ，後彎症では33\%であった。

推計学的に平衡異常合併率について比較検討 したところ，金柱正常例，後彎症例，側彎症例 それぞれの間に明らかな有意差が証明された。 また，平衡異常の合併率は病的姿勢の後彎症， および側彎症において正常例よりあ明らかに高 く, 病的姿勢のうちでも側彎症例の平衡晎常合 併率は後彎症例のそれよりあ明らかに高いこと が立証された。

すなわち，側彎症例には平衡異常を高率に合 併することが明らかにされた，同時に佱柱の異 常彎曲に伴う病的姿勢と言って屯，平衡機能の 面からみると側彎症と後彎症とではその意義が 明らかに異なることあ推測せしめられた。すな わち，春柱の生理的彎曲は必ず前後面にあり， 側面にはない，前後彎では常に左右対称性が保
たれるに反し, 側彎では左右対称性が保たれず, 常に非生理的である. 従って前後彎症は生理的 彎曲の増強とみなされるに反し，側彎症は非生 理的彎曲であり，病的彎曲とみなすととあ可能 である。このようなととからも，側彎症の平衡 異常合併率が後彎病のそれよりあ高いととは当 然亡思われる。

ところで，側彎症における平衡異常の内訳を 見ると，その検査所見で明らかなように，軀幹 や上・下肢に不安定性ないしフラッキが見られ るだけでなく，眼にあ眼振あるいは眼振様運動 のような不安定性ないしはフラッキが見られる ことが解る．との事実は極めて貴重であり，特 記すべき所見である。すなわち，軀幹や四肢な

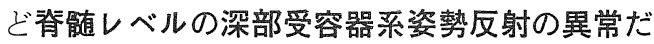
けでなく，脳幹レベルの視運動性反射中枢の異 常が証明されるという重要な事実が発見された というととである。このととはまた同時に行わ れた実験的眼振検査，すなわち，視運動性眼振 検査によって71.80，の高率に異常が証明された という事実によってあ支持される所である. 周 知の通り，視運動性眼振検査は，脳幹部の機能 検査として重要な位置を占めるあのであって， silent area と屯いわれる脸幹部の脳波と屯みな されている.

ところで，側彎症の平衡異常の合併率をその 主たる原因別に分けて比較してみると，先天性 側彎症（椎骨の先天性奇形による側彎症）17例 では平衡異常を示すむの 9 例で53\%陽性，症候 性側彎症（側彎の発生原因の明らかなもの）17 例では平衡異常を示すむの12例で71\%陽性，特 発性側彎症（発生原因不明の侧彎症）116例では 平衡異常を示すむの98例で84\%陽性であった。 しかしながら，推計学的には先天性側彎症，症 候性側彎症，特発性側彎症それぞれの平衡異常 合併率の間には有意差を証明するととができな かった．したがって，側彎症における平衡異常 は側彎の原因に関係するよりは側彎の状態その 
ものに関係すると考えられる.

ところで，側彎はその原因の如何を問わず成 長期を通じ進行性増覀の傾向を示すのをその特 徵としている，そして，成長終止期に入れば側 彎の進展は一応停止するのが常である.

それで，側彎症を成長期のあのと成長終止期 の屯のに分けて平衡異常の合併率を比較してみ た. 成長期の側彎症では90\%，成長終止期のそ れでは $37 \%$ で，両者の間に有意差が証明され た。この事実は極めて貴重であり，注目さる心゙ きととと考える。

しかも，その平衡異常の程度は側彎進行の著 明な成長期において高度であり，成長終止期に 移行し側彎の進行が停止するに従い次第に軽度 となり，20才頃になれば側彎はあってあ平衡異 常は，全く消失するととが明らかにされた（図 $1)$.

このととは，平衡異常が成長と関係し，側彎 の進展と密接な関係があるととを示している. ととろで，成長というものはこれを物理的に

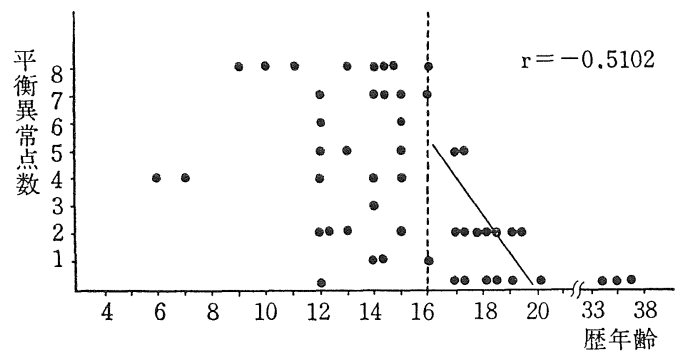

図 1 年齢之平衡異常点数

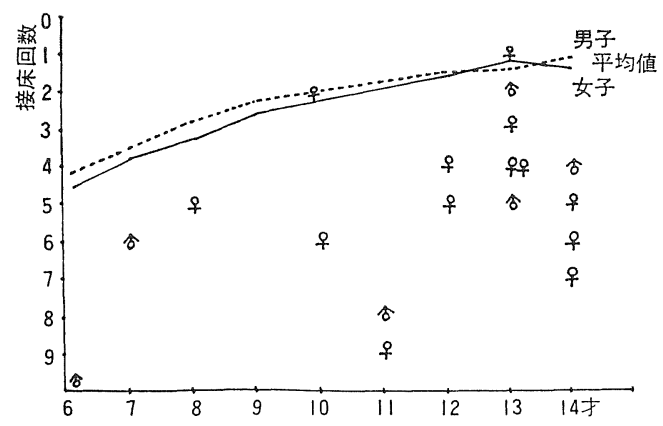

図 2 側彎症学童之平衡機能
みれば，身長の増加に伴う体重心の上昇に外な らない。重心の上昇は不安定化への移行を意味 するので，生体は平衡能の発達によって不断に 調整してれに対処する必要がある。乙の調整が 不調の場合には姿勢保持機構に破綻を生じ，側 彎症のような姿勢異常が発生して屯よい。

この点を明らかにするため，私共は小・中学 童 6,650名について平衡能の発達之側彎発生の 関係について野外調查を行なった。乙れによる と，平衡能は年令とともに次第に発達し，ほぼ 10才にして成人並みの水準に達するととを知っ た。側彎症はこれら学童の約 1\%（構築性側彎 $0.3 \%$ ，機能性側彎 $0.7 \%$ ）に発見された。この 数字は干葉大 ${ }^{6)}$ をはじめ本邦各地で行なわれた 最近の野外調査成績と大差を見ないあのであ る。私共の調査では，乙のような側彎症は平衡 能発達に迤延のみられる学童に多発し，女子に 多いことが知られた（図 2).

このととは, 成長に対応すべき平衡能の発達 がないと，乙れを背景として側彎症が発生し得 るととを証するあのと考える。

2）臨床実験

(1) 側彎と平衡異常との関係に関する実験的 研究

特発性側彎症患者 9 例に対し治療を兼衫次の ような実験的研究を行なった。すなわち，乙れ らに対し Active Corrective Plaster Jacket 法 （山田)（図 3 ）を施し，側彎を能動的に矯正した ところ，いずれの例でも側彎度は一様に改善せ られ，平均 $40.7 \%$ 矯正が得られた(図 4)。乙 れらの例について矯正法施行 4 周間後平衡機能 を検査したところ平衡異常評価点数（配点基準 は表 1 の通りで最高を 8 点満点(表 1 )）に抢い て3.4点の低下を示した。. これらの例について ギプスの固定を除去したととろ矯正度に扣いて 29.7\%の戻りを見せ，平衡機能に扔いて屯一様 な悪化を示し異常評価点数に㧊いて平均 2.1 点 増加した.さらに，平均 5 力月間能動矯正法を 継続したところ，側彎度に扔いて46.0\%，平衡 機能に扣いて4.9点の改善が認められた(図 4 ). 


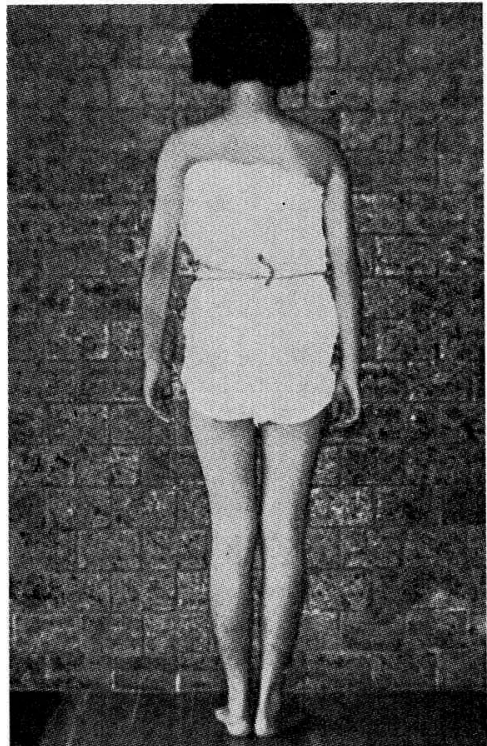

図 3 Active Corrective Plaster Jacket
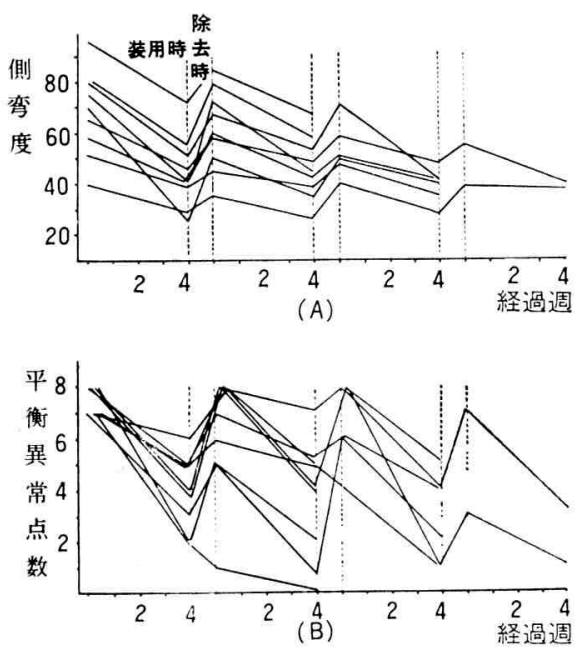

図 4 側彎度 (A) と平衡異常 (B) の推移 -Active Corrective Plaster Jacket 装用—

ともかく，以上の経過に掞いて，側彎の改善 あるいは悪化と平衡機能の改善あるいは悪化と の間に平行的な関係が見られたことはことに興 味深いととであった。

ところが，側彎度の改善がもたらされず，か えってこれを悪化せしめるようなギプス固定が 行なわれた 1 例では平衡機能は改善されず，む
表 1 平衡異常の点数評価

1. 立ち直り反射検査
i) 両脚直立検査
ii）単脚直立検查
陽性…… 1 点
iii) Mann の檢査. 陽性……............. 1 点
iv) Goniometer 検査 陽性 ……......... 1 点

2. 偏倚検查

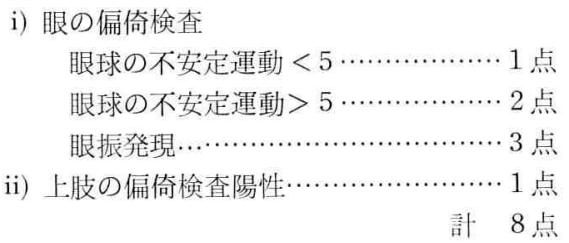

しろ悪化した.

次のような事実から，側彎症患者における平 衡異常は側彎度の推移と密接な関係があること を確認した.

(2) 側彎症患者における体重心の上方推移と 平衡機能との関係に関する実験的研究

成長期の側彎症には有意の差をもって平衡異 常が極めて高率に合併し，成長終止期の側彎症 には固定した彎曲変形があるに拘らず平衡異常 の合併率は極めて低率であった，成長の問題 は，全身的には成長ホルモン，局所的には成長 軟骨の観点からも検討されねばならないが，体 平衡との直接的な関係を求めることは極めて困 難である.しかしながら，物理的観点から，成 長を体重心の不断の上方推移とみなすならば, 条件設定は極めて容易となる.

特発性側彎症の 10 才子次て, 卧位，坐 位，立位と体位を転換せしめ，視運動性眼振を 検査した。視運動性眼振は重心位置の低い卧 位，坐位より立位へと上方に推移せしめるに従 って視運動性眼振の解発が不良になるととが解 った（図 5 ). すなわち，側彎症患者は体重心の 上方推移により平衡機能に障害を来すととが明 らかにされた。

このととから，成長期の側彎症患者の平衡異 常は体重心の上方推移と関係があるように思わ れる。 
重心の上方推移に伴なう視 運動性眼振

10才，ㅇ，特発性側彎症 円筒右回し 5 秒 1 回転

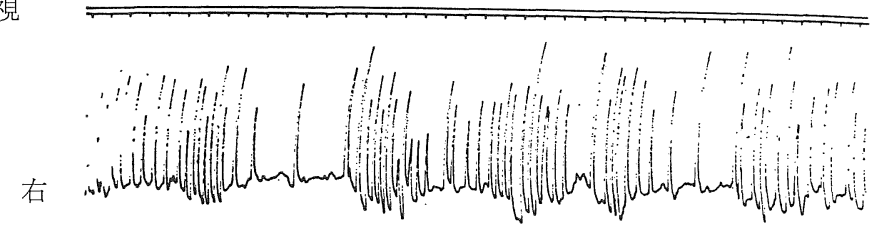

立位
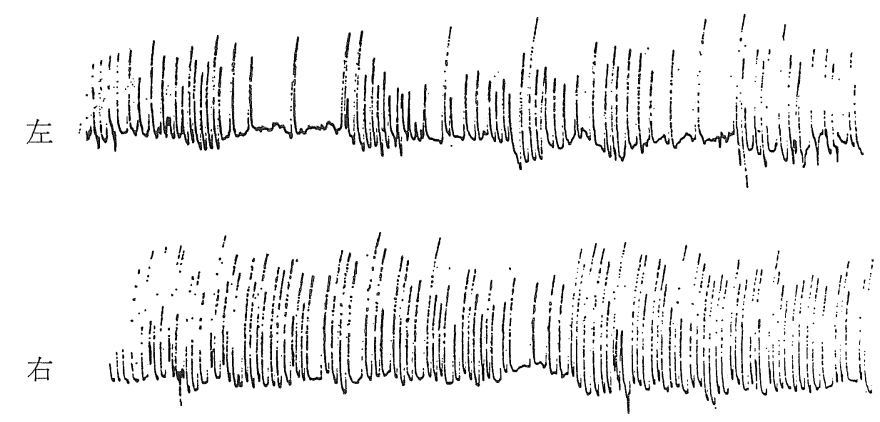

坐位
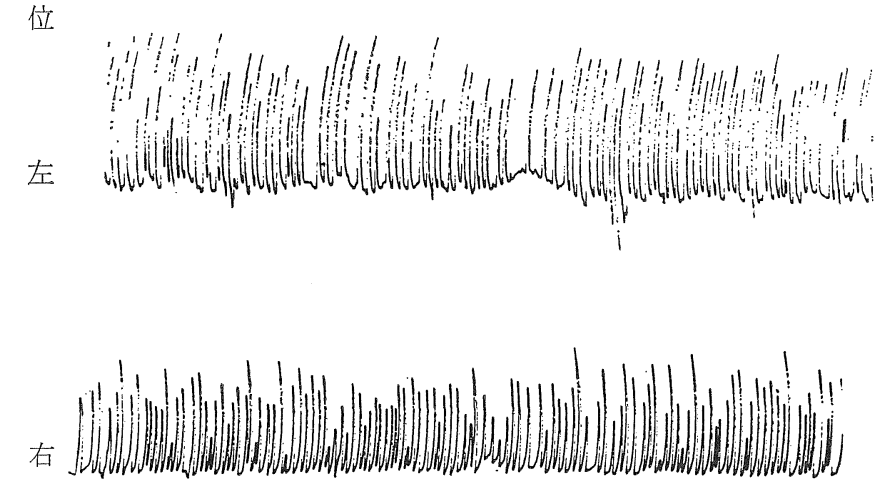

臥位

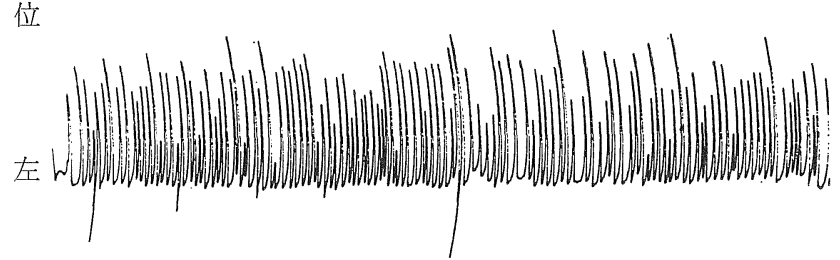

図 5

(3) 軀幹筋活動と平衡機能との関係に関する 臨床実験

側彎症 31 例，平均年齢14.2才のものにつき彎 曲頂椎部付近の傍脊柱筋部（凸側およびロ側） に表面電極を貼布し，多元同時誘導で筋電図を 記録した。対照として同年齢層の健常者15名が
選ばれた。

立位の状態では，本症31例中23例 $(74.2 \%)$ の多数に軀幹筋活動の左右差が認められた。乙 のうち眼に偏倚現象の見られた屯のは20例，見 られなかったあのは僅かに 3 例 (9.7\%) であ り，明らかな有意差を以て側彎症には軀幹筋の 
表 2 Seven Cases with Organic Brain-Stem Abnormalities

\begin{tabular}{|c|c|c|c|c|c|c|c|c|}
\hline \multicolumn{2}{|c|}{ Case } & $\begin{array}{c}\text { Degree } \\
\text { of } \\
\text { curve }\end{array}$ & $\begin{array}{c}\text { Onset } \\
\text { of } \\
\text { scoliosis }\end{array}$ & $\begin{array}{c}\text { Onset of } \\
\text { oculomotor } \\
\text { dysfunction }\end{array}$ & $\begin{array}{l}\text { Spontaneous } \\
\text { nystagmus }\end{array}$ & $\begin{array}{l}\text { Voluntary } \\
\text { eye } \\
\text { movement }\end{array}$ & $\begin{array}{c}\text { Body } \\
\text { equilibrium }\end{array}$ & $\begin{array}{c}\text { Optokinetic } \\
\text { nystagmus }\end{array}$ \\
\hline 1 & $9 \mathrm{y}$ 우 & 69 & $2 y$ & infant & $\begin{array}{l}\text { horizontal } \\
\text { jerking }\end{array}$ & $\begin{array}{l}\text { holizontally } \\
\text { disconjugated }\end{array}$ & abnormal & no reaction \\
\hline 2 & 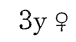 & 20 & $2 y$ & $2 y$ & "I & " & undetected & undetected \\
\hline 3 & $13 \mathrm{y}$ 우 & 75 & $6 y$ & $\begin{array}{l}\text { soon after } \\
\text { birth }\end{array}$ & "l & "I & abnormal & $\begin{array}{l}\text { inhibition } \\
\text { inversion }\end{array}$ \\
\hline 4 & $13 \mathrm{y}$ 우 & 65 & $10 y$ & "l & /1 & normal & /" & "I \\
\hline 5 & $12 \mathrm{y}$ 우 & 51 & $8 y$ & "I & $\begin{array}{c}\text { "I } \\
\text { (latent) }\end{array}$ & normal & "I & inhibition \\
\hline 6 & $9 y \hat{o}$ & 12 & $9 y$ & $9 y$ & $\begin{array}{l}\text { horizontal } \\
\text { jerking }\end{array}$ & normal & /l & $\begin{array}{l}\text { inhibition } \\
\text { inversion }\end{array}$ \\
\hline 7 & $13 y$ \&ै & 18 & $11 \mathrm{y}$ & unknown & (latent) & normal & $/ /$ & inhibition \\
\hline
\end{tabular}

異常活動と眼の偏倚現象が合併していることが 知られた。対照15例ではこのようなととは全く 認められなかった。

また，成長期の側彎症 24 例では19例 (79.1\%) に, 成長終止期の 7 例では僅かに 1 例 (14.3\%) に軀幹筋活動之眼運動の異常の合併が認めら れ，成長期と成長終止期のあのとの間には有意 差が証明された。また，成長期のものでは側彎 が高度となるに従い眼と稫幹筋活動の異常の合 併屯高率であった。しかし，成長終止期のもの ではこのような関係は認められなかった。

なお，このような偏側優位の躳幹筋活動は胸 椎部より腰椎部に最もしばしば認められ，腰部 の異常筋活動と眼の偏倚現象との間には緊密な 関係があるととが知られた。このととは姿勢反 射の観点から特に注目に価する.

また，側彎を矯正すれば，嵒幹筋活動の異常 あ軽減あるいは消失し, 眼の偏倚現象もこれに 伴って軽減あるいは消失した。

すなわち，成長期の側彎症においては，偏側 優位の軀幹筋活動之眼の偏倚現象との間に極め て密接な関係があり，両者が側彎度の增減と密 に関連していることが知られた。同様な所見は 視運動性眼振検査によっても得られた。いずれ にせよ，乙のような事実は，稫幹の深部受容器 系之脳幹部平衡中枢の間に feedback 機構が存 在するととを推定せしめる.
以上のような臨床調査, 野外調査ならびに臨 床実験を通して，側彎症の成立について次のよ うな機転を考えた。すなわち，側彎症は深部受 容器系と脳幹部平衡中枢の間に張りめぐらされ た反射回路を介する悪循環形成によって成立 し, 成長期を通ずる体重心の不断の上昇に伴っ て進行性增悪を示す姿勢異常であると考えた。

そして，原因の明らかな先天性側彎症や症候 性側彎症については，その悪循環形成の主導的 因子が末梢の深部受容器系にあると推定され, 原因不明な特発性側彎症については, 墨循環形 成の主導的因子が脳幹部平衡中枢の異常にある と考えられた.

3）脳幹部平衡中枢に関する臨床的検討

特発性側彎症においては, 障害の主座が脳幹 部平衡中枢にあると推定されたが，その平衡異 常は Active Corrective Plaster Jacket による能 動的ギプス矯正で改善され可逆的変動を示すと とから，機能的障害と推定された。このような あのは特発性側彎症119例中 112 例，94\%占めて いた。

ところが残りの 7 例， $6 \%$ は神経学的検査7 によって脳幹部平衡中枢の器質的障害と診断さ れた。これらの症例はいずれあ先天性の眼運動 系異常之高度の体平衡異常を合併し，成長期を 通じ極めて強い進行性側彎を呈した。乙の眼運 動系異常は Jerking Type の眼振で, 視運動性 
眼振の解発が著明に抑制されていた(表 2 )。こ のうち 4 例は神経学的にあ障害の局在性が推定 され PPRF (Paramedian Zone of the Pontine Reticular Formation)，または MLF (Medial Longitudinal Fasciculus) 症候群と診断された。 そして，乙れら脳幹部平衡中枢の器質的障害例 に打ける側彎進展機構屯, 多数例を占める上述 機能障害例と同じく, 深部受容器系と脳幹部平 衡中枢間の反射回路を介する悪循環形成によっ て側彎の進行性増悪がもたらされたものと考え る.

同様な症例について邱8) は 3 例， Dretakis9) らは 5 例を報告している。乙れらには，いずれ あ脳幹部における何等かの障害が推定されてい る。しかし，現在までのところ，乙のような症 例についての剖検所見の報告は見られない。と ころが，てれとよく似た疾患で，平衡失調を主 徵とし高率に進行性側彎を合併する Familial Dysautonomia ${ }^{10)}$ というユダヤ系小児に発生す る中枢神経疾患がある。乙れは予後不良で剖検 所見屯報告されている．Fogelson'11) らは中枢 神経系の特異な所見として脳幹部，特に延䯣や 橋の網様体や Schülz 束，脊䯣視床路などに局 所的脱䯣，上向性後索や脊䯣小脳路の䯣鞘消失 などの病理学的所見をあげている.

とあかく，乙のような症例はきわめて稀であ るとは言え，脳幹部平衡中枢の器質的障害の在 存を立証するあので極めて貴重である。そし て，側彎症の成立に関しる私共の平衡異常説に 対し有力な支持を与えるあのと考える.

以上の臨床的研究に対し以下の如き実験によ り裏付けを行なった。

4) 側彎の発生と平衡障害に関する実験的研究 側彎の発生には重力が大きな影響をむってい る.この意味から実験動物としては起立歩行動 物が望ましい，私共は価格の点や観察の利便, 飼育の難易などの面から二足鼠を選んだ.

二足臼の作製法は Goff-12)-坂本氏 ${ }^{13)}$ 変法に準 じて行なったが，生後 1 2 週間後の Wistar 系 白鼠新産仔をを冬眼麻酔下で両上肢抽よび尾を
できるだけ短かく結紮切断し，母国に哺育せし めた。 離乳後（生後 $4 \sim 5$ 週）餌と水を適当な 高所に吊して飼育し，起立歩行在誘導訓練す る. このようにして鼠に二足歩行能を獲得せし めることができる.

(1) 側彎と脳幹部平衡中枢の機能障害に関す る実験的研究

中川14) は二足鼠に対し飲料水として $0.05 \%$ $\mathrm{HCl}$-Semicarbazid 溶液を与え側彎を発生せし めてその平衡機能の推移を視運動眼振所見を指 標として追究した．ところで，Wistar 系白鼠 のような赤目の Albino Animal には視運動性 眼振を解発せしめるととは本来非常に困難なと とである。

そこで，特殊な工夫を施してての困難を克服 した。すすおち，離乳後動物を暗い飼育箱に移 し，餌投与の直前にその都度黄色豆電球を点灯 するという操作を繰り返し，給餌と電灯の関係 を学習せしめ，餌に電灯を条件づけた。このよ うにして光点に対する動物の注視能力向上をは かった．視運動性眼振検査を実施するにあたっ てはオーム型大円筒の黒線毎に一定の高さに黄 色豆電灯を吊し，乙の光点を刺激源として 30 秒 1 回の等速回転を行なった. 動物の眼運動は眼 振電計で誘導記録した。

対照を含め27匹の白瓦が実験に供されたが， Semicarbazid 投与の二足鼠では投与後 $5 \sim 9$ 週 (生後10１4週）で $10^{\circ} \sim 17^{\circ}$ の側彎が発生し 次第に進展した。 ところが，側彎の発生ととあ にそれまで良好に解発されていた視運動性眼振 が著明に抑制されるととが解った。しかし，側 彎の発生しなかった動物ではそのようなととは 全くなかった。 あっとあ，乙のような視運動性 眼振の解発抑制は Semicarbazid の影響でもな く，二足性の影響でもないととが対照実験によ って確認された。したがって，上記の実験は， 側彎の進展とと屯に視運動性眼振の解発が抑制 されたと考えるととは妥当であり，側彎の進展 とともに脳幹部平衡中枢の機能低下が起こり得 るととを立証した実験と思われる。 
(2)脳幹部平衡中枢の器質的障害と側彎発生 に関する実験的研究

私共は侧彎症例について精密な平衡神経学的 検索を行ない脳幹部平衡中枢に器質的障害の推 定される 7 例を発見した。そして，その障害の 主座が Medial Longitudinal Fasciculus あるい は Paramedian Zone of the Pontine Reticular Formation にあると彰断した。 それで，この 部を実験的に破壞し側彎を発生せしめ得るや否 や検討しようと試みた。

田村15)は離乳後間屯ない79匹の二足鼠につ いて脳幹部を電気的に定位破壊し最長 395 日間 にわたってその経過を精しく観察した、脳幹部 破壊操作後24匹（30\%）は，5週間以内に死亡 するという極めて消耗率の高い実験ではあった が，幸に55匹（70\%）はそれ以上生存した。

脳幹部破壊後平衡異常は79匹中68匹 (86\%) はいろいろな形で出現した。すすおち，自発眼 振, 眼球偏倚, 立ち直り異常, 姿勢異常などであ った。このような著明な平衡異常が 5 週間以上 にもわたり継続し，起立能力を回復した二足鼠 8 匹に側彎の発生が見られた。側彎の発生時期 は脳幹破壊後 $7 \sim 16$ 週, 生後 $12 \sim 22$ 週で弫の成 長旺盛期にあたり，彎曲は成長期を通じ增覀し た。しかし，平衡障害が発現しなかったもの や，平衡障害が出現しても5 週間以内に消失し たあの，あるいはそれが5 週以上継続しついに 起立能力を回復し得なかったものからは 1 匹屯 側彎の発生が見られなかった。

側彎を発生した動物 8 匹中事故によって粉失 した 1 匹を除き 7 匹について剖検を行なった。

これらの例では脳幹部の破壊部位に共通性があ るととが確認された。すなわち，その破壊部位 は中脳の中心灰白質で Schütz 束が含ま机てい た。うち 1 匹では破壊が両側M L F にまで及ん でいた(図6).

関野 ${ }^{16)}$ の研究によれば Schütz 束は視床下部 と脳幹部網膜体との間に緊密な線維連絡を有す ることが立証されている。したがって，この部 の障害が平衡異常之共に自律神経異常を招来す

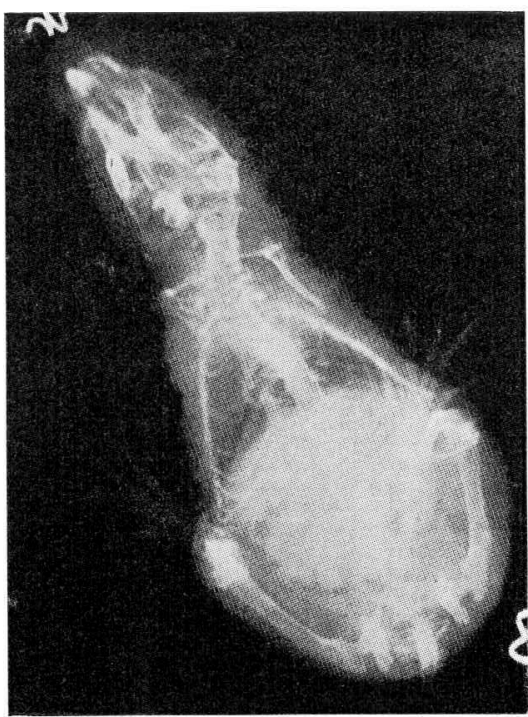

定位脳幹破壊 2 足鼠に発生した奉柱側彎

破壊部位
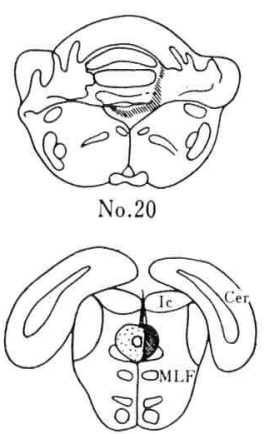

No. 23

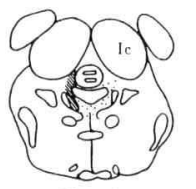

No. 37

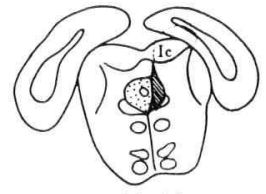

No.46

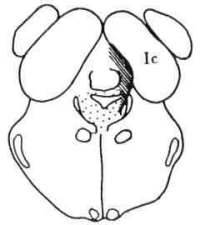

No. 53

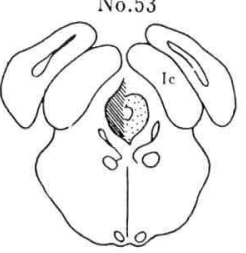

No. 58

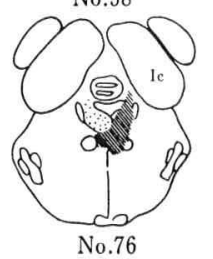

側彎 2 足国の慆幹破壊部位

図 6 
るととあ考えられる。

とあかく, かくして発生せしめた脳幹部網様 体の器質的障害が姿勢反射機能に破綻を生じ, 要循環を招来して二足鼠に側彎を発生せしめた あのと考える.

な打，本実験の結果から側彎症に掞ける自律 神経系異常合併の可能性も推定せしめるが，臨 床の実際面であ立証できることである。ただ し，乙れに関しては，既に「脊柱側彎症の成因 に関する研究——特に解発性側彎症に対する Neurohumoral-approach」17)として発表してい るので，乙こでは深く触れないとととする。
ともかく，との実験で脳幹部の器質的障害が 側彎症発生の原因となり得ることを明確に立証 したあのと考える。

以上，側彎症の平衡機能障害について臨床と 実験の両面からその存在を確認し，乙れに基い て作業仮説を立て，Active Corrective Plaster Jacket なる治療法を案出した。この治療法の 適応や効果については既に多数例について実証 されており，度々報告しているとてろであある ので，紙数の関係上，乙れに関する記載は割愛 させて載くことにする。

\section{III.ま と め}

1）側彎症は軀幹の非対称的変形を示す姿勢異常であり，その大部分において原因不明である. 脊柱の彎曲は成長期を通じて進行性に増悪し，成長終止期に至りその進行を停止するという特異な 疾患である.しかむ，その発生頻度がきわめて高く，社会的にも重視さるべき疾患である.

2）本症の解明にあたっては，部分より全体へ，分析より総合へというような発想の転換が必要 である。 そこで, 脊柱をその構成体の個々に分析して解明するという従来の方法から脱皮し, 脊柱 を軀幹の中軸として全体的，総合的に把握し，姿勢異常という観点から平衡神経学的に解明を進め ることにした.

3）臨床検査の結果，本症には原因の如何を問わず平衡異常が高率に合併し，しかもそれは成長 期に㧍ける側彎進展と密接な関係があることが知られた。 そして, 最もしばしば眼の偏倚現象や視 運動性眼振異常を伴うことから，従来考えられていたような脊髄レベルの平衡異常だけでなく，脳 幹レベルの平衡異常と考えられた.

精密な平衡神経学的検査により，脳幹部平衡中枢の障害には機能的障害と器質的障害の 2 種類が あることが知られた．前者は本症例の大多数を占め，後者はきわめて少数である.

と屯かく，側彎症は，軀幹の深部受容器系と脳幹部平衡中枢の間に張りめぐらされた反射回路を 介して体平衡の悪循環が形成せられ，乙れが成長という不断の体重心上昇を伴う不安定期を背景と して，側彎の進展がもたらされたものと推定された.

4）以上のような側彎症の発生，進展に関する私共の推定は，ギプス矯正，体位変換，筋電罒な ど種々な臨床実験を通してその妥当性が支持された.

5）側彎症の平衡機能異常に関する臨床的事実は幼若二足鼠を使用した次のような実験的研究に よってその信憑性が裏付けられた。すなわち，中川は側彎の進展とともに脳幹部平衡中枢の機能低 下が起こることを実験的に立証たしし，田村は脳幹部を定位破壞し，てれに器質的障害を与えるこ とによって平衡異常と側彎を発生せしめ，私共の説に明快な実験的根拠を与えた.

以上により，脊柱側彎症が姿勢平衡の破綻によって発生し，成長期を通じて進行性増悪を示すて とが明瞭に立証された次第である。とてろで，乙の研究は第 1 頸椎レベルをむって整形外科の守備 範囲の上限界としていた従来の整形外科に対し，それより数框上方の脳幹レベルまで研究領域を拡 大すべきことを示唆するすのであって，整形外科学界に新展開を期待するという意味で重要な価值 を持つあのと考える. 
此の度，檜教授は母校京都大学の教授として栄転されることになったが，一層の御発展をお祈りする次第であ る. 人生における10年の価值は誠に大きい。乙の貴重な出合の中で育まれた学問と友情は無限な生命を得てさら に伸びて行くであろうが，別れはやはり寂しい，健康を祈り度々の再会を期し度い。

ここにお互の機縁となった研究のまとめを小論文として呈上する次第である.

文

1) Haglund, F.: Orthopädie als Arbeits-und Lehrfach, Verh. Dt. Orth. Ges. 19. Kongr. 1924.

2) Edelmann, P.: Das Krankheitsbild der Skoliosenformen, Orthopädie Technik, 26 Jrg. 41, 1975.

3) Risser, C.: Scoliosis: Past and Present, J. Bone \& Joint Surg., 46A : 167, 1964.

4) Hauser, E. D. W.: Curvature of the Spine, Charles C. Thomas, Springfield, 1962.

5）山田憲吾ほか：側彎症と体平衡機能, 日整会誌, $41: 101$, 炤 42.

山田憲吾, 檜 学: 脊柱側彎と体平衡 ( I ), (II)，耳鼻臨床，61：3，昭43.

山田憲吾, 檜 学: 脊柱側彎と体平衡 (III), (N)，耳鼻臨床，61：169，昭43.

山田憲吾, 山本博司 : 脊柱側彎症と体平衡機能, 臨床整形外科, $3: 470$, 昭 43 .

山田憲吾, 山本博司 : 脊柱側彎症における体平衡 に関する神経学的考察, 臨床整形外科, 3:479, 昭43.

山田憲吾ほ力：脊柱側彎症に対する矯正，機能訓 練，機能ギプス固定法 (Active Corrective Plaster Jacket) の治療体系に関連して, リハビリテーシ ョン医学, $6: 201$, 昭 44 .

山田憲吾ほか：側彎症治療における平衡機能の意 義, 中部整災誌, $11: 151$, 昭 43.

Yamada, K. et al: Equilibrium Function in Scoliosis and Active Corrective Plaster Jacket for the Treatment, Tokushima J. exper. Med., 16: 1, 1970 .

山田憲吾ほか：平衡機能獲得と脊柱側彎症，日整 会誌, $44: 891$, 昭 45 .

山田憲吾ほ力：平衡機能獲得と脊柱側彎症発生に 関する野外調査, 中部整災誌, $13: 883$, 昭 45 .

Yamada, K. et al: Equilibrium Function in Scoliosis and Active Corrective Plaster Jacket for Treatment, Pediatrics Digest, 12: 23, 1970.

Yamada, K. et al.: A Neurogical Approach to the Etiology and Therapy of Scoliosis: J. Bone \& Joint Surg., 53-A: 197, 1971.

山田憲吾 : 脊柱側彎と平衡, 姿勢シンポジウム論 文集, 137 , 姿勢研究所, 東京, 昭46.
献

山田憲吾ほか：側彎症と平衡機能，その基礎と臨 床, 日整会誌, 45:862, 昭 46 .

山田憲吾ほか：脊柱側彎症の成因に関する研究 一一特に特発性側彎症に対する Neurohumoral Approach一一, 臨床整形外科, $8: 539$, 昭 48 .

山田憲吾, 山本博司 : 脊柱側彎症, リヒビリテー ション処方集, 368, 医学書院, 東京, 昭 47.

山田憲吾 : 頸部・腰部疾患でおてるめまい, 平衡 失調一一側彎症と平衡機能異常—, 治療, 57 : 1251, 昭50.

6) 鈴木次郎, 井上駿一: 脊柱側彎症, 整形外科の進 歩, 第 9 集, 85, 南江堂, 東京, 昭 40 .

7）山田憲吾ほ加：先天性眼運動系異常を有する春柱 側彎症一一特に脳幹性要因について—，臨床整 形外科, $4: 935$, 昭 44 .

Tezuka, A.: Development of Scoliosis in Cases with Congenital Organic Abnormalities of Brainstem, Tokushima J. exper. Med., 18: 49, 1971.

8）邱 伸男：脊柱值彎症に伴う水平共同眼球運動障 害の 3 例, 眼科臨床医報, $59: 482$, 昭 40 .

9) Dretakis, E. K., Kondoyannis, P. N.: Congenital Scoliosis Associated with Encephalopathy in Five Children of Two Families, J. Bone \& Joint Surg., 56-A: 1747, 1974.

10) Yoslow, W. et al.: Orthopedic Defects in Familial Dysautonomia, J. Bone \& Joint Surg., 53A: 1541, 1971.

11) Fogelson, M. H. et al.: Spinal Cord Changes in Familial Dysautonomia, Arch. Neurol., 17: 103, 1967.

12) Goff, C. W. and Landmesser, W.: Bipedal Rat and Mice, Laboratory Animals for Orthopedic Research, J. Bone \& Joint Surg., 37-A: 1188, 1955.

13）坂本謙一: Bipedal Rat による骨変形の研究, 四 国医誌，14:1149，昭34.

14）中川幸夫 : 脊柱側彎症と姿勢反射の実験的研究, 中部整災誌, $14: 332$, 昭46.

中川幸夫 : 脊柱側彎症の姿勢反射に関する実験的 研究, 四国医誌, $32: 155$, 昭51.

15）田村大司：定位脳幹破壊 Bipedal Rat に打ける奉 
柱側彎症の実験的研究, 中部整災誌, $13: 881$, 昭 45.

田村大司, 山田憲吾, 山本博司 : 定位脳幹破壊 2 足鼠の姿勢反射異常之脊柱側彎症, Equilibrium Research, 29: 30, 1971.

田村大司：定位脳幹破壊二足ネズミに括ける脊柱 側彎症の実験的研究, 日整会誌, $48: 137$, 昭 49 .

16）関野卜シ子：Nauta 法による中脳の実験解剖学的 研究一一特に中心灰白質の線維結合について—, 解剖学雑誌, $34: 211,1959$.
17）山田憲吾ほか：脊柱側彎症の成因に関する研究 ——特に特発性側彎症に対する Neurohumoral Approach一一, 臨床整形外科, $8: 539$, 昭 48 .

岸 浩: 特発性側彎症患者に抢ける内分泌代謝 機能についての研究, 四国医誌, $32: 169$, 昭51.

原稿到着日 : 昭和51年 8 月 15 日
別刷請求先 : 山田 憲 吾
徳島大学本部学長室付
徳島市新蔵町

